\title{
The Economics of Labour Shortage: Three Case Studies from Northern Borneo
}

\author{
Christopher Colclough and Martin Godfrey
}

Underutilisation of labour is rightly regarded as one of the most serious and difficult problems facing the world today. Not all economies however, are equally affected by it. Some - whether as a result of mineral resource endowment or of favourable labour/land ratios - are grappling with the opposite problem of labour shortage. This article considers three such 'labour shortage' economies: Brunei, Sabah and Sarawak. Each of them are oil producers. But the oil sector has had a somewhat different role in each economy and has contributed differently to the emergence of a shortage of labour. The article is in three sections: the first defines the concept of labour shortage; the second describes its incidence in each state; the third examines some policy solutions.

\section{Definitions of Labour Shortage}

The condition of labour shortage requires careful definition. Perhaps the simplest way to approach it is through its antithesis: labour surplus. In a classic labour-surplus economy, as described by Lewis (1954), the existence in the subsistence sector of workers of 'negligible, zero or even negative' marginal productivity makes available to the capitalist sector an unlimited supply of labour at a constant real wage. However, this phase of unlimited supply lasts only as long as marginal productivity of workers in the subsistence sector is zero. Once this removable labour surplus is exhausted, the supply curve of labour to the capitalist sector turns upwards. On the weakest definition of labour shortage (as the absence of labour surplus) it might be deemed to exist if the capitalist sector's demand curve for labour cuts the supply curve at a point where the supply curve is upward-sloping. Thus in the modified Lewis diagram of Figure 1 , if the demand curve is $D_{1}$ there is a labour surplus, if $D_{2}$ a labour shortage.

A test for the existence of labour shortage in this sense might be the progress of real wages over time. Persistent, strong upward movement of real wages would be consistent with such labour shortage
Figure I

Demand for and Supply of Labour in the Capitalist Sector - a Weak Definition of Labour Shortage

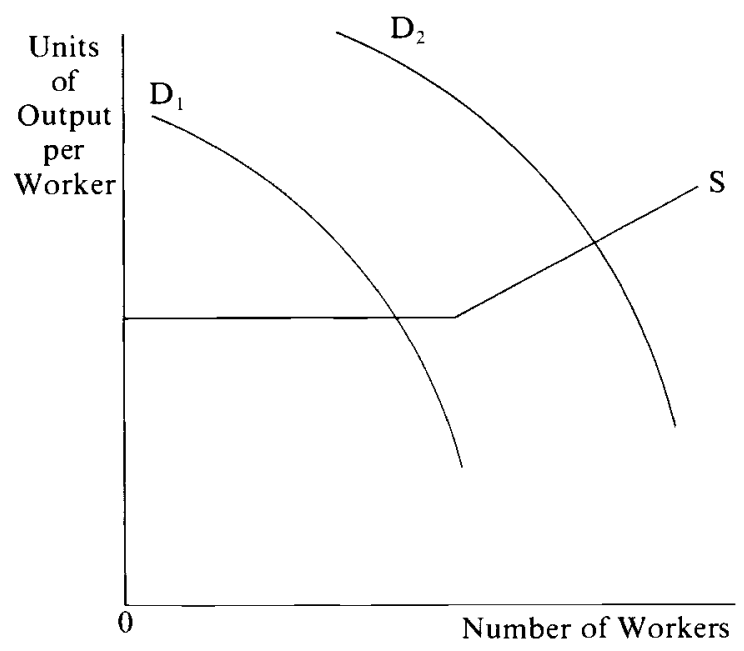

although there might be other explanations for it, such as minimum wage legislation, trade union organisation, or increases in the cost of transfer from the subsistence to the capitalist sector.

However, on this definition a large number of economies might be judged to have a labour shortage. Something stronger is needed. Labour shortage might be taken to imply not only that employers must increase their wages if they want to add to their labour force, but also that they are willing to employ, at the existing real wage, more workers than are currently employed and willing to work at that wage. In theory, provided the wage level is free to equilibrate demand and supply, persistent shortage of labour - manifest in a high level of vacancies at current wage levels

IDS Bulletin. 1986, vol 17 no 4. Institute of Development Studics. Sussex 
-should occur only during short 'adjustment' periods. Thus, a sustained high level of vacancies for unskilled labour would normally be associated with constraints preventing the emergence of a marketclearing wage. In Figure 2, for example, if the wage were prevented from rising from $W_{1}$ to $W_{2}$, the market-clearing level, a shortage of workers manifest by vacancies equivalent to $L_{1} L_{2}$ would persist. Under this interpretation, then, if the meaning of 'shortage' is to be non-trivial (i.e. not synonymous with 'scarce') it would occur endemically only if wages were not free to adjust upwards in response to an increase in demand.

Figure 2:

\section{Wage-induced labour shortage}

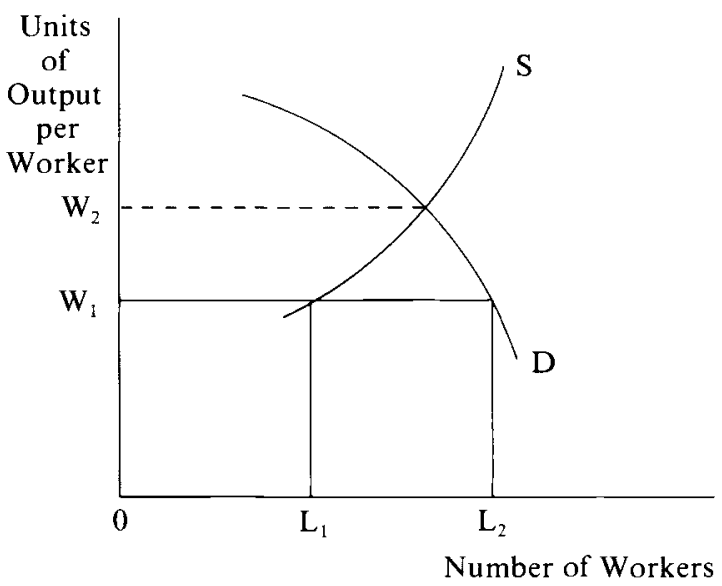

Under some market conditions, however, labour shortage, defined as above, could occur without delivering sustained upward pressure upon the real wage. This is illustrated in Figure 3. Thus, at wage OW employers would be willing to employ $\mathrm{OL}_{2}$ workers. However, at this wage only $\mathrm{OL}_{1}$ workers offer themselves for employment, implying a gap between maximum demand and supply of $L_{1} L_{2}$. It can be seen that this shortage will not be resolved by marketdetermined movements of the real wage.

This situation, of course, implies an unusual shape for the marginal product of labour curve, from which the demand curve is derived. However, a 'kinked' marginal product curve is possible in cases where, at the margin, employers' actions have no impact upon the market price of their product, and where fixed capital is a negligible proportion of total costs. This can be so, for example, where the price of an export good is fixed in terms of foreign exchange, and where the main factor inputs are land, labour and variable
Figure 3:

'Endemic' labour shortage in the capitalist sector

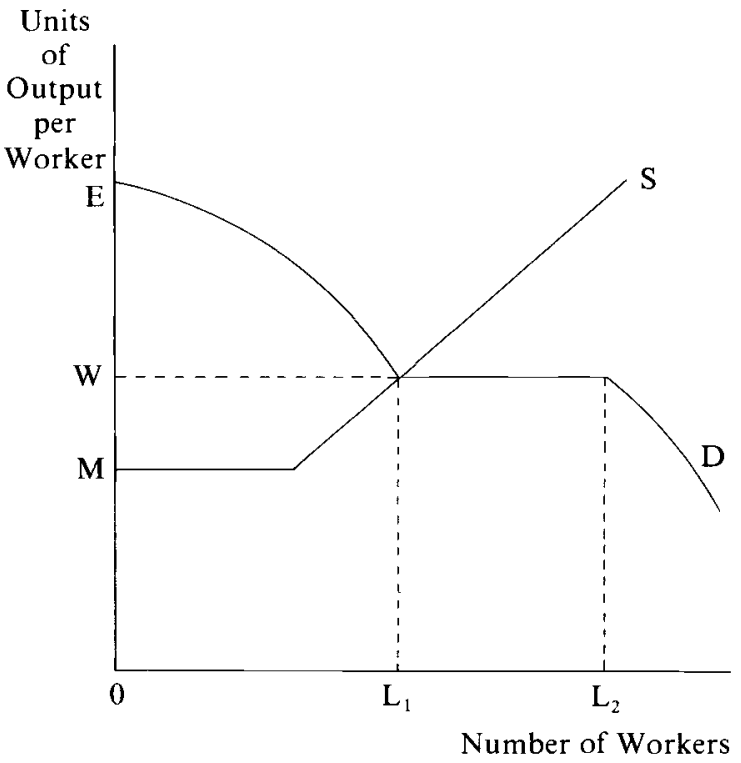

capital. These conditions are approximated in the production of some types of agricultural exports. Thus in estate agriculture, provided there is no land constraint, the marginal product of labour could effectively be constant over a fairly large range of output values. It will be shown that the above analytic tools are helpful in attempting to understand the nature of labour shortage in the three economies in question.

Shortage of labour in an economy does not necessarily imply an absence of underutilisation. Indeed, the more frequent and intensive the shortage, the greater the internal labour slack. Also, shortage of labour in one sector of an economy may coexist with and be aggravated by underutilisation in another sector; thus even in market economies, over-expanded government services sectors may starve productive sectors of workers. It may be wrong to describe these phenomena as problems, since some are fairly easily resolvable. But different means of resolving them have different consequences, and they often raise quite complex problems of policy.

\section{Labour Shortage in the Three Economies}

Brunei, Sabah and Sarawak are situated in the northern part of the island of Borneo, which they share with the Indonesian provinces of West, Central, South and East Kalimantan to the South. Brunei is a sultanate which gained full independence from Britain 
at the end of 1983. Sabah and Sarawak are states within the Federation of Malaysia, but separate labour markets to the extent that they require work passes of other Malaysians as well as of foreigners working within their borders. Each of these economies is affected by shortage of labour, but for different reasons. These will be discussed in turn.

The Brunei economy, with a population in 1985 of around 225,000 people, is dominated by the production of oil and gas. This sector accounts for 90 per cent of GDP and 95 per cent of government revenue (Table 1). The oil/gas sector itself employs only a small proportion (about five per cent) of the active labour force. Although a large proportion of Brunei's oil revenue is invested overseas (the income from which, together with current oil/gas production, has helped to provide Brunei with one of the highest levels of income per capita in the world) enough is spent at home to generate a chronic shortage of labour. One aspect of this is the very high rate of formation of capital, mostly in the form of buildings and infrastructure, the construction of which reached a peak during the run up to independence. The other substantial non-oil sectors are retail trade and banking, finance, insurance, real estate and business services.

However, the most important aspect of the domestic spending of oil revenues is the expansion of the civil service, to the extent that in 1981 the public sector absorbed 47 per cent of all employees and as many as 76 per cent of Brunei citizen employees. Further, it accounted for 44 per cent of non-oil GDP. As a result of its dominance, the public sector appears to set the supply price of labour to the rest of the economy. This does not necessarily mean that government wages are always higher than those in the private sector at every level. Nevertheless the government is the wage leader in the dynamic sense of being the employer in relation to whom other employers set their wage levels. Citizens prefer the status and security of a government job and the government establishment is allowed to expand to absorb those who want such jobs. The private sector, under pressure to employ more citizens, has to raise its wages to bid them away.

The general situation of labour shortage does not mean that unemployment is completely unknown. The 1981 census revealed an unemployment rate

Table 1

Comparative Data: Economies of North Borneo, Circa 1980

\begin{tabular}{|c|c|c|c|}
\hline & Sabah & Sarawak & Brunei \\
\hline $\begin{array}{l}\text { Population } \\
\text { of whom: non-citizens }\end{array}$ & $\begin{array}{r}1,100,000 \\
245,000\end{array}$ & $\begin{array}{r}1,500,000 \\
7,000\end{array}$ & $\begin{array}{r}200,000 \\
50,000\end{array}$ \\
\hline GDP growth $1970-80$ (p.a.) $(\%)$ & 10 & 13 & 12 \\
\hline $\begin{aligned} & \% \text { of GDP from: agriculture } \\
& \text { forestry } \\
& \text { oil and gas }\end{aligned}$ & $\begin{array}{l}11 \\
28 \\
12\end{array}$ & $\begin{array}{r}7 \\
16 \\
30\end{array}$ & $\begin{array}{l}0.5 \\
0.1 \\
90\end{array}$ \\
\hline \% of Government revenue from: oil and gas & 20 & 45 & 95 \\
\hline Savings as $\%$ of GDP & 40 & 50 & 70 \\
\hline Capital Formation as $\%$ of GDP & 25 & 28 & 40 \\
\hline $\begin{aligned} \text { Active labour force: citizen } \\
\text { non-citizen }\end{aligned}$ & $\begin{array}{l}250,000 \\
100,000\end{array}$ & $\begin{array}{r}460,000 \\
6,000\end{array}$ & $\begin{array}{l}43,000 \\
24,010\end{array}$ \\
\hline $\begin{array}{l}\% \text { in agriculture } \\
\text { oil and gas } \\
\text { forestry } \\
\text { government }\end{array}$ & $\begin{array}{l}58 \\
0.7 \\
3 \\
19\end{array}$ & $\begin{array}{l}53 \\
0.7 \\
5 \\
15\end{array}$ & $\begin{array}{r}1 \\
\frac{5}{47}\end{array}$ \\
\hline Citizen government employees as $\%$ of total citizen employees & 26 & 15 & 75 \\
\hline Unemployment rate & 8 & 5 & $5^{1}$ \\
\hline Female participation rate & 43 & 51 & 30 \\
\hline
\end{tabular}

Note: ${ }^{1}$ The rate is negligible for males, but around $10 \%$ for females

Sources: Population censuses, National accounts and authors' estimates 
among citizens of over five per cent. This mainly affects females. The rate for males, at less than three per cent, is hardly more than frictional, but 10 per cent of the female citizen labour force are unemployed. This in turn reflects the virtual doubling of the female participation rate over the ten years to 1981 , reflecting significant increases in real wages over the period. Alongside and aggravating labour shortage, also, there is massive underutilisation of labour in another sense. It would be possible to remove a large number of people from their current activities. This removable labour surplus [what Sen $(1975: 36)$ calls the 'production aspect' of underutilisation] is usually found in agriculture but in Brunei's case it is located in the bureaucracy.

Thus, the non-oil sectors of the Brunei economy are high wage service sectors. As in some other previously agricultural oil-producing economies suffering from 'Dutch Disease', agriculture has withered away, and manufacturing has been stifled under the impact of a high real exchange rate induced by oil revenues. High real wages in services plus domestic labour shortage largely explain this situation. It implies, however, that the constraints preventing long-term diversification of production away from dependence on oil are exceedingly difficult to overcome.

The other two economies are far less dominated by oil and gas production than is Brunei. In the case of Sabah, this sector accounts for 12 per cent of GDP and around 20 per cent of government revenue. Equally, although the proportion of the labour force working in agriculture has been falling over the past few years, at 58 per cent in 1980 it was still fairly high. So too is the proportion of the workforce represented by ownaccount and unpaid family workers (44 per cent in 1980 compared with 55 per cent ten years earlier), a sign of the continued importance of the small holding sectors. Thus the economic structure, and the composition of employment are much less dominated by oil, and more strongly focused upon agricultural production than is the case in Brunei.

There is, however, a shortage of labour in the formal sector. The major cause is the low ratio of labour to cultivable land. Overall population density is less than 14 per sq $\mathrm{km}$, and even density per sq $\mathrm{km}$ of land of moderate and high agricultural potential is only 46 persons, compared with 87 in Peninsular Malaysia, 165 in the Philippines and 630 in Bangladesh. By no means all of the population, however, are eligible to hold land. The Chinese Malays, who comprise about one quarter of the population, and the immigrant groups (comprising a further quarter) are ineligible for the receipt of a 15-acre smallholding which is the right of Bumiputera households. Thus, the other cause of labour shortage has been the rapid growth of the formal economy over the past decade, led by the extractive sector. Formal employment growth has been more than sufficient to absorb the available labour supply from both indigenous and nonindigenous groups, causing an acute labour shortage - particularly in the construction and agricultural estates sectors.

The shortage of labour has been aggravated by the expansion of the public sector, though again not to the same extent as in Brunei. Having grown at an annual average rate of over six per cent since 1969 , the public sector employed over 66,000 people in 1983 , equivalent to about 40 per cent of all employees outside the smallholder agricultural sector. Part of this growth has been due to the creation of statutory bodies in productive sectors of the economy (a strategy which has not been particularly successful) but these account for only about 15 per cent of total public sector employment.

Although large, the government can hardly be said to dominate the local labour market. Basic salaries are fixed by the federal government and, although a regional allowance is also paid, this has perhaps prevented public-sector salaries from rising as high as they otherwise would have during the oil and timberbased boom of the 1970s. Large manufacturing firms appear to pay considerably more than government to all grades of workers, and statutory bodies which are tied to government salary scales have difficulty in attracting and retaining the scarce manpower that they need. Although smaller firms pay slightly below government scales for most categories, the government does not seem to be the wage leader in the dynamic sense that the Brunei government is.

As in Brunei, shortage of labour coexists with various forms of underutilisation. On the normal international definition ('not working' and 'seeking work') the unemployment rate revealed by the 1980 census, at 3.0 per cent, is quite low. If the 'seeking work' criterion is relaxed (as it arguably should be, particularly in rural areas where it does not make much sense to seek non-existent wage employment) the rate rises to 7.9 per cent. Females, particularly in rural areas (where their unemployment rate on this definition is 10.5 per cent) are disproportionately affected. So too, according to the 1980 Labour Force Survey, are the young (the unemployment rate for the 15-19 age group is 25.4 per cent), the relatively well educated (particularly those with lower and middle secondary schooling) and new entrants to the labour force (70.9 per cent of the unemployed have never worked before). Thus, there are mismatches here (by gender, age, education and training and geographical area) but there also seems to be an element of search unemployment, as those with higher levels of 
education take time to adjust to the deterioration in their labour market prospects that has accompanied educational expansion.

The case of Sarawak is similar to Sabah, but somewhat more complex. Demand for and supply of labour are here more evenly balanced - although at present shortages of unskilled labour predominate. The oil sector is proportionately more important than in Sabah - yet remains small in comparison with Brunei (30 per cent of GDP, 45 per cent of government revenue). Nevertheless output and employment growth in the formal sector has, as in Sabah, been an important means of minimising the emergence of surplus labour, particularly amongst non-indigenous groups.

Population density in Sarawak is very low (approximately 10 persons per square kilometre), but the proportion of cultivable land is much smaller than in the case of Sabah. However, to a greater extent, the Sarawak economy is still dominated by smallholding agriculture, producing mainly for subsistence. In 1980 61 per cent of the working population was in the agriculture, hunting, forestry and fishing sectors and 59 per cent were own-account and unpaid family workers. The pace of recent change has been rapid ( 10 years earlier these agricultural sectors had accounted for 68 per cent and own-account and family workers for 73 per cent of the workforce) but Sarawak is clearly still in an early stage of transition from a peasant/subsistence to a capitalist economy.

Returns to smallholding are not high but they still seem to be high enough to push the supply price of labour to agricultural estates and land schemes above what they can afford to pay. In contrast to Sabah, the estates sector in Sarawak is at present very small, consisting of only 15 estates and 24 land schemes, with a total of less than 19,000 hectares in production of rubber, oil palm, cocoa and (on a tiny experimental scale) tea. Private estates, employing only l,200 people in 1984, with an average basic wage of $M \$ 199$ per month for agricultural workers (plus some non-cash benefits such as housing) can only at tract about one third of the local agricultural workers that they need. Public sector estates and land schemes (where wages are much better) report to have only about half the labour that they need.

The extent to which expansion of public-sector employment has aggravated labour shortage is probably less in Sarawak than in the two neighbouring territories. At around 67,000 in 1984 total employment in the public sector was equivalent to 32 per cent of formal-sector employment and 13 per cent of the labour force. Thus the weight of the public sector in the labour market is much lower than in Brunei and
Sabah. As in Sabah, also, federal determination of salary scales has probably meant that public-sector remuneration has risen more slowly than if local factors had been the dominant influence. As a result (if age and eduation are controlled for) average monthly wage earnings in the private sector are considerably higher than in the public sector and there is no evidence of government being regarded as a wage leader in the labour market.

The extent of underutilisation of labour (coexisting with shortage) also seems to be less than in the neighbouring territories. The 'active' unemployment ('not working' and 'seeking work') rate is, at 1.4 per cent in 1980, even lower than in Sabah. If the 'inactive' unemployment of those not working but not actively seeking work is added in, the rate rises, but only to 5.4 per cent, again much lower than in Sabah. 'Search' unemployment among young school-leavers is important; more than half of the state's unemployed have never worked before, almost half have been unemployed for less than three months and 31 per cent have at least some secondary schooling. The unschooled unemployed ( 42 per cent of the total) tend to be older and predominantly female. Female unemployment (particularly inactive unemployment) rates are much higher than those for males; in addition, the female participation rate (though still high at 51 per cent in 1980) has been falling, which might signify a withdrawal from the labour force of women unable to get suitable jobs. The existence of mismatches is indicated by the fact that 42 per cent of unplaced registrants on the Manpower Department registers at the end of 1983 were looking for clerical jobs, which represent less than 16 per cent of wage employment.

A further complication in the analysis of Sarawak's labour market is the large number of its workers who are working outside the state, not only in Brunei, Singapore, West Malaysia and Sabah, but also in the Arab region, Thailand, Indonesia, Australia, Venezuela and the North Sea [Kedit 1984]. For instance, in Brunei alone there were almost 13,000 Sarawakian workers in 1981, representing more than half of the sultanate's foreign workers. More than three quarters of them were in the skilled-and-below production-worker category, with construction workers predominant. This phenomenon (which has its origin in the traditional 'rite of passage' of young males known as bejalai ${ }^{1}$ but now probably reflects economic pressures) shows that while the supply price of labour to some wage-employing sectors of the domestic economy is above their demand price, it is not high in comparison with the demand price of employers in some other labour-shortage economies.

1 See Freeman (1955 para $320 \mathrm{ff}$ ) for a description of bejala $i$ as it used to be, and Kedit (1984) for a more contemporary account. 
Internally, on the other hand, it remains the case that Sarawak's labour market - in common with those of Sabah and Brunei - is one in which shortages have outweighed surpluses of labour.

\section{Policy Options in the Face of Labour Shortage}

Faced with a shortage of labour, there are a number of policy options open to employers and/or their governments. In what follows, these are briefly examined.

\section{(a) Increasing Female Participation}

Female participation rates have always been high in Sabah and Sarawak and remain so ( 43 and 51 per cent respectively in 1980), largely as a reflection of the continued importance of agriculture. Women tend to remain in the agricultural labour force while bringing up young children. In non-agricultural, Moslem Brunei the rate is much lower (33 per cent for citizens in 1981) but has increased very fast in recent years; in 1971 the comparable rate had been only 17 per cent. Women have indeed represented a reserve which has increasingly been pulled into the labour force as the shortage has intensified, and scope for further increases in their participation rate remains.

\section{(b) Intersectoral Labour Transfer}

When the sector within an economy that is hoarding and underutilising labour is government, the process of bidding labour a way from it to other labour-scarce sectors requires the cooperation of government. So far the Brunei government, which employs more than three quarters of Brunei citizens, has shown no signs of such restraint. At the top end of its salary scale it absorbs all those who have received government scholarships; at the bottom end, thousands of dailypaid workers appear to be beyond the control of the establishment department. Its salaries and fringe benefits (and the processes for increasing them) appear to be such as to make it extremely difficult for the private sector to attract local employees.

In Sabah and Sarawak, on the other hand, where there is more doubt about the extent of underutilisation of labour in the public sector, the federal government has cut real recurrent spending since 1983 . This is partly because the fall in prices and volumes of some of its export commodities have affected government revenue. But it also reflects its belief that the public sector in Malaysia is too large by the standards of other countries and that there are significant inefficiencies and overstaffing in many departments, and its wish to see the private sector as the main engine of growth. Thus the growth in public sector employment is likely to be restrained in these two states, to the benefit of labour supply to other sectors of their economies.

\section{(c) Export of Capital}

All three economies, in a sense, export capital. As their contribution to the federation of which they are members, Sabah and Sarawak export a large part of the tax revenue obtained from their oil industries; both state governments retain revenue equivalent to five per cent of the value of their petroleum output, with the remaining tax revenue going to the federal authorities. The export of capital from Brunei to the rest of the world is massive. The surplus of government revenue over expenditure at the height of the oil boom in 1981 was more than $\$ 6,000 \mathrm{mn}$, equivalent to 68 per cent of GDP, and by the end of 1982 overseas assets of the Brunei government were estimated at $\$ 25,000 \mathrm{mn}$. Thus, while none of the three territories sees this as a deliberate strategy to escape the consequences of labour shortage, the shortage would probably be more acute (at least in the short term) if these transfers did not take place.

\section{(d) Importing Labour}

Perhaps the only policy measure that has been deployed explicitly to alleviate labour shortage in all three territories is the import of cheap labour. This has proceeded furthest in Brunei, where immigrant workers represented 36 per cent of total employment in 1981. There, the vast majority of foreign workers are in skilled and below-skilled occupations, with only 14 per cent of them holding professional/technical/ managerial jobs. Ironically more than half of foreign workers come from Sarawak (a cheap-labour area in relation to Brunei) which accounts for particularly high proportions of immigrant construction workers.

Sabah, too, is heavily reliant on immigrant workers, especially in its agricultural estates. According to the population census, there were 87,000 non-Malaysian workers in the state in 1980 , about a quarter of the total working population. This figure is probably an underestimate, yet it represents a substantial increase since the early 1970s. 43,000 of the non-Malaysians enumerated in the census were in agricultural occupations. The other main occupational concentration of foreign workers was the 4,000 (mainly Filipino) bricklayers, carpenters and other building workers, 41 per cent of the total number of workers in these occupations. Only 1,500 non-Malaysian professional, technical and managerial workers were enumerated, seven per cent of all workers in these categories and two per cent of all immigrant workers.

Sarawak is poised to move along the path already trodden by Brunei and Sabah, being as yet potentially rather than actually reliant on immigrant workers. According to the population census there were less than 5,400 non-Malaysian workers in the state in 1980, not much more than one per cent of the total working 
population. Well over half of these were agricultural workers, while production workers, particularly in the construction industry, accounted for a further 20 per cent. There were fewer than a thousand foreign professional, technical and managerial workers (less than four per cent of the total number of workers in these categories). A relatively large number of Malaysians from outside Sarawak are also working in the state $(3,900$ in all), three-quarters of them in the public sector and 60 per cent of them as teachers.

Thus it appears that in a normal year the number of non-Sarawakian workers in the state is more than counterbalanced by the large number of Sarawakians working outside (see above). However, not all years are normal. In 1981, for instance, at the height of a major development scheme in the town of Bintulu, 5,800 work passes were issued to South Korean building workers, all of whom have since returned home. Moreover, plans are under consideration for a spectacular expansion of the agricultural estates sector. At present this is tiny, employing no more than 6,500 workers in private and public estates and land schemes in 1984. There is a possibility that such employment might be tripled by 1994 and might exceed 37,000 by the end of the century. The difficulties of attracting local workers to the estates have already been discussed. If such expansion occurred it would have to be based very largely on immigrant labour. This would not raise the state's dependence on foreign workers to Brunei/Sabah proportions but it might mean an increase in their percentage of the working population from one to five per cent by the year 2000 .

The possible impact of extensive use of immigrant labour (on a Brunei/Sabah scale) can be illustrated with the aid of our previous diagram. If in Figure 4 the supply curve for local workers remains as MSD and the employers' demand curve remains unchanged at ED, the impact upon the domestic wage and employment situation of importing workers depends on their number and their supply price.

The unlimited supply curve for foreign labour, FV, indicates a supply-price for foreign labour, OF, which is less than the minimum supply price for domestic labour, OM. As before, with no importation of labour the economy faces a labour shortage, with employment stable at $\mathrm{OL}_{1}$, and at a real wage level of $\mathrm{OW}$. As importation of labour begins, the total supply curve $\left(\mathrm{S}_{\mathrm{D}}+\mathrm{SF}_{\mathrm{F}}\right)$ moves outwards, increasing total employment with, initially, no impact upon the level of the real wage $O W$. It can be seen that $L_{1} L_{3}$ units of foreign labour can be employed without reducing either the level of citizen labour $\mathrm{OL}_{1}$ or the wage $\mathrm{OW}$.

However, importation of labour beyond $L_{1} L_{3}$ begins

\section{Figure 4}

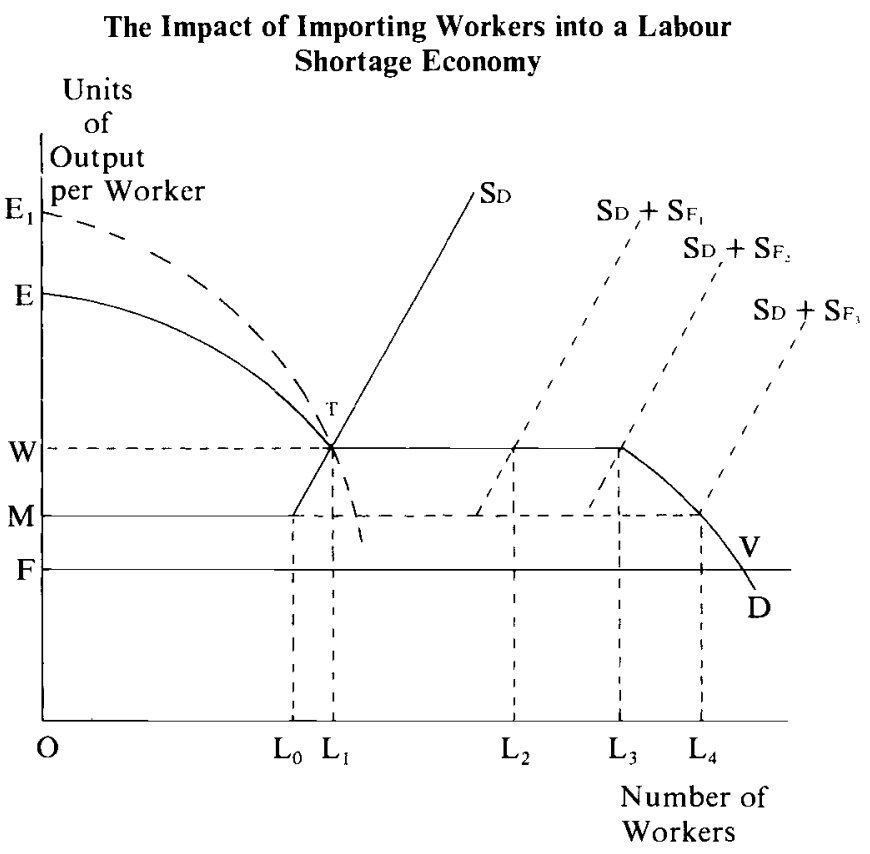

to reduce both the levels of citizen employment and real wages. For example, at an employment level of $\mathrm{OL}_{4}$ the wage would fall to $\mathrm{OM}$, and citizen employment would be reduced from $\mathrm{OL}_{1}$ to $\mathrm{OL}_{0}$, with $\mathrm{L}_{0} \mathrm{~L}_{4}$ foreign workers being employed. Beyond this point, no citizen workers would be employed, and the wage would fall to OF.

This is a fairly accurate illustration of the current state of the market for agricultural wage workers in the case of Sabah, which operates a virtual open-door immigration policy as far as less skilled workers are concerned. For instance, Indonesians recruited by employers, directly or through middlemen, are issued with work-passes which are transferable to any employer. Filipinos classified as refugees have the right not to be deported. There is also a significant amount of illegal immigration. Thus the number of Sabahan workers on the estates has been reduced to near zero. Those who are unwilling to work at 'immigrant' wages have taken employment in other sectors of the economy or (the ultimate support of the supply price $O M$ ) have remained in or reverted to smallholding.

Employers in the estates sector would argue (probably correctly) that importing labour is the only way to earn adequate profits in an unfriendly world market, given existing techniques of production. As Figure 4 shows, profit with an entirely immigrant labour force 
(EVF) is larger than with an entirely indigenous one (ETW).

\section{(e) Labour-saving Technical Change}

However, there is another option - the introduction of labour saving techniques. Diagrammatically this would have the effect of changing the slope and shape of the demand curve. In Figure 4, for example, it might imply a move outwards and upwards from ET to $E_{1} T$ with some reduction or even elimination of the 'kinked' portion of the curve owing to increased capitalisation of the production process. This would allow the profitable employment of a smaller, entirely local, high productivity labour force at a wage that was in line with the supply price.

In practice, planters in Sabah are, as might be expected, sceptical about the scope for such changes in technique. There seem to be variations from crop to crop. For instance, the Palm Oil Research Institute, Malaysia, has sponsored research into labour-saving possibilities, and already spraying equipment and technique have changed from high-volume to ultralow-volume; further advances look possible in aerial and other mechanical applications of fertiliser and chemicals; harvesting and planting have so far defied mechanisation, but the research continues. In the case of rubber, clearing and planting are mechanisable; the Rubber Research Institute is working on the mechanisation of tapping but with little success so far.

Labour-saving technical change in cocoa estates would involve wholesale replanting and redesign of layouts, but is possible in principle. In general, mechanisation would involve overhauling plantation systems, to suit the crop to the machine, rather than incremental change in existing systems - and the problem is that there is no incentive for employers to embark on such an upheaval, as long as they are assured of a continued adequate supply of cheap Indonesian labour.

In the absence of labour-saving technical change the effect of denying employers access to cheap imported labour would probably be (at current world commodity prices and exchange rates) the closure of most agricultural estates and the transfer of their land to another use compatible with higher wage labour. Whether this was of net benefit or cost to society would depend on a variety of factors, including a comparison of the profitability of with-migration agriculture and the without-migration alternative, and of the use to which profits would be put in each case (for instance, how much is expatriated or used in non-productive ways, how much taxed and/or reinvested locally?). In any such comparison the fundamental long-run question would be whether the import of cheap labour was preserving the economy's comparative advantage in a low-productivity, lowtechnology sector with limited growth potential and thus preventing the structural change that would otherwise occur in the face of labour shortage.

A final point that needs to be emphasised in any appraisal of the strategy options open to a labourshortage economy concerns the viewpoint from which that appraisal is being made. So far the point of view adopted has been that of the labour-importing society and economy. Clearly within such a society there are different interests that would be differently affected by the import of cheap labour. This has been implicitly recognised in our discussion of its impact on wages and profits. For example, in Figure 4, importation of $\mathrm{L}_{1} \mathrm{~L}_{3}$ foreign workers will increase both output and total employment without sacrificing the levels of either citizen employment or the real wage. Beyond $\mathrm{L}_{1} \mathrm{~L}_{3}$, however, this situation is reversed as both the wage and citizen employment levels begin to fall. This result would normally offend domestic policy objectives, even though levels of output, profitability and total employment continue to rise. Thus, an appraisal of policy benefits based upon maximising world or regional welfare would come to different conclusions from one based entirely on national (or territorial) considerations.

Labour shortage economies exist in a world of surplus labour. For every Brunei or Sabah there is an Indonesia or Philippines. Migration of labour from low-wage to high-wage economies is in the short-run interests of supplier states, virtually by definition. Thus, expansion of agricultural estates in Sabah and Sarawak and a continued public-sector 'pension for life' for all Brunei citizens would undoubtedly be welcomed by those in neighbouring South East Asian countries who would be offered the chance of an escape from wretched poverty. However, this paper has shown that if the domestic labour market is nonsegmented, such a strategy is compatible with the likely wage and employment objectives of importing states only under special circumstances, and for a fairly tightly defined quantity of imported labour. Thus, in some economies, the extent to which production adjustment can occur following an oilboom, is highly constrained by the political implications of labour importation, and by the effects such a strategy is allowed to have upon levels of citizens' renumeration.

\section{References}

Freeman, J. D., 1955, Report on the Iban of Sarawak, Government Printing Office, Kuching

Kedit, P. M., 1984, 'Bejalai is changing Iban society', Sarawak Gazette, Kuching, April 
Sen, A. K., 1975, Employment, Technology and Development, Oxford University Press
Lewis, W. A., 1954, 'Economic development with unlimited supplies of labour', The Manchester School 